\title{
Moderating Effect of Dynamic Capabilities on the Relationship between Entrepreneurial Orientation and Business Performance of Small and Medium Enterprises
}

\author{
Joan Bii" and Robert Onyango^ \\ \#Kisii University, Kenya \\ ^Masinde Muliro University, Kenya \\ Received 15 Aug 2018, Accepted 17 Oct 2018, Available online 20 Oct 2018, Vol.6 (Sept/Oct 2018 issue)
}

\begin{abstract}
This paper reviewed past literature with the aim of establishing the trends in published literature on dynamic capabilities, entrepreneurial orientation (EO) and business performance of Small and Medium Enterprise's (SMEs). Based on this review the relationship between dynamic capabilities, entrepreneurial orientation and business performance of SMEs is hinged on Schumpeter theory of innovations, (Schumpeter, 1942) and dynamic capability theory by Teeceet al (1997). Scholars have a common view that the association between EO and business performance is too complex hence moderated by variables. Dynamic capabilities (DC) have a moderating role between predictors of competitive advantage and business performance. The literature reviewed therefore presents the empirical studies globally and locally on moderation of dynamic capabilities on EO and business performance of SMEs. From the review it has been established that there are inconsistent findings in terms of relationships between DCS, EO and performance of SMES which is justified by the fact that DCs, EO dimensions vary independently and may not be equally valuable across performance metrics or different stages of development of SMEs, besides different situations impacts on the relationship between $D C S, E O$ and business performance of SMEs. In addition there is a dearth of literature on the moderating effect of dynamic capabilities on the relationship between $E O$ and business performance thus calling for further interrogation in the context of developing countries. In conclusion there are mixed results in the linkage between EO and business performance, however effective integration and implementation of EO and DC would help the organization secure competitive advantage in the face of dynamic business environment to foster high business performance.
\end{abstract}

Keywords: Dynamic Capabilities, Entrepreneurial Orientation, Business Performance

\section{Introduction}

The global economy has been fostered by the Small and Medium Enterprise's (SMEs) as they remain the fulcrum of growth of gross domestic product (GDP) by reducing the level of unemployment and promotion of entrepreneurial activity. The role of SMEs in the development of the country is significant (Bayati \& Taghavi, 2007). Besides SMEs, especially those operating in developing countries take a proactive role in supporting governments and investment promotion agencies in creating concrete Sustainable Development Goals (SDGs) related project pipelines (Weber \& Bolwijn, 2014). However the failure rate of SMEs remains high throughout the world (Fang, Yuli, \& Hongzhi, 2009). In this regard the ostensibility of SMEs as a strategic stimulant for economic growth remains fragile. This has

*Corresponding author's ORCID ID: 0000-0003-3323-3313

DOI: https://doi.org/10.14741/ijmcr/v.6.5.18 invoked substantial and growing interest in the small and medium enterprises with no exception to their business performance (Hamel \& Coimbatore, 2010).

SMEs survival and performance is increasingly dependent on a number of factors including resilience of SMEs to refocus some of their strategies (Gunasekaran, Rai\& Griffin, 2011). It therefore behooves SMEs to be dynamic and competitive in order to survive, grow and have superior business performance. In the converse when SMEs remain adamant to the changes in their environment they become victims of inordinate closures and stagnation. This is underscored by the fact that business performance of SMEs is negatively or positively influenced by changes in the business environment (Zhang, van Doorn, \& Leeflang, 2014). Competition, management experience, technology change and finance have been incriminated as the greatest obstacle to growth and performance of businesses, (FinMark., 2010; Singh, Garg, \& Deshmukh, 2010; Sharmilee \& Muhammad, 2016). All these together without 
prejudicedenotes the essence of entreprenurial orientation and dynamic capabilities in enhancing performance of SMEs.

The role of dynamic capabilities and entrepreneurial orientation in enhancing performance of SME borrows from Schumpeter's theory of innovations, (Schumpeter, 1942) and dynamic capability theory by Teeceet al., (1997). This is because entrepreneurial orientation combined with organizational reconfiguring capabilities constitutes a potential source of competitive advantage (Ari, Kaisu, \& Saarenketo, 2005). Entrepreneurial orientation is a strategy-making process that provides organizations with a basis for entrepreneurial decisions and actions (Rauch, Wiklund, Lumpkin, \& Fresse, 2009). There are five developed dimensions of Entrepreneurial Orientation, namely innovativeness, reactiveness, competitive aggressiveness, risk taking and autonomy (Dess\& Lumpkin, 2005). Entrepreneurial orientation combined with organizational reconfiguring capabilities through dynamic capabilities therefore constitutes a potential source of competitive advantage (Ari, Kaisu, \& Saarenketo, 2005).

Dynamic capabilities are processes which help a firm attain and keep up a competitive advantage over other firms despite an ever changing business environment (Gathungu \& Mwangi, 2012; Helfat, et al., 2007). Dynamic capability improves response speed efficiency and effectiveness with respect to dealing with environmental changes to positively affect SMEs performance by allowing the SMEs to take advantage of revenue attractive opportunities and adjust its process to cut expenses (Drnevich \& Kriauciunas, 2011). SMEs need dynamic capabilities that enable them to sense and seize new opportunities and renew the existing market base. The business environment is always changing and hence SMEs have to adapt quickly to competition and new challenges through continuous renewal of their competence. This is in line with the argument of Mwangi, (2016); Mwangi and Kiiru, (2017); Adomako, (2017), who opined that dynamic capabilities have a moderating role between drivers of competitive advantage and performance.

\subsection{Trends in published literature}

Global Entrepreneurship Monitor (GEM) Reports (20012010) show that SME survival and business performance is one of the lowest in the world (Herrington, Kew, \& Kew, 2010). Therefore it remains incumbent for SMEs to adopt $E O$ and DC so that a country can benefit from them. Entrepreneurial orientation (EO)has received substantial conceptual and empirical attention, representing one of the few areas in entrepreneurship research (Rauch et al, 2009). Trends in literature also show the positive influence of entrepreneurial orientation in various performance measures such as financial performance, growth of the firm and overall business performance (Davis, et al., 2010; Rauch, et al., 2009).
However, studies by Gholami\&Birjandi, (2016) Simiyu, Namusonge, and Sakwa, 2016; Muthee and Karanja, 2014; Vishal and Safal, 2015 revealed a positive significant relationship between EO and business performance. Rauch, et al., (2009) revealed that there is a moderately large significant relationship. However, these findings are not uncontested .Inconsistencies have also been revealed on the effect of different dimensions of EO on business performance (Ndesaulwa\&Kikula, 2016; Udin\& Bose, 2014; Tachia, et al., 2016; kamendi, 2016). Affendy, Asmat-Nizam, and Farid, (2015); Auger, BarNir, and Gallaugher,( 2003); Smart and Conant, (1994) revealed no significant relationship between EO and performance of SMEs. (Hart, 1992) argues that entrepreneurial-type strategies may even be associated with poor performance.

Differences in findings may be attributed to differences in research design or methodological idiosyncrasies because it is difficult to draw general conclusions on the basis of single studies examining single samples, in particular if response rates are low. It is also possible that certain variables moderate the relationship between the two (Rauch, et al.,2005). However, the relationship between EO and business performance remains complex because different patterns of relationships may form in different contexts. This scenario indicates the need for a moderating variable and reveals a condition such that EO influences business performance (Wales, Gupta, \& Moussa, 2011). The significant role of a moderating variable indicates that the positive relationship between EO and FP is often conditional (Aluisius \& Rosli, 2015).

Some of the studies on EO and business performance of SMEs were qualitative for instance Ndesaulwa \& Kikula, (2016) while others adopted a mixed method approach, Udin\& Bose, (2014); Rauch, Wiklund, Lumpkin, \&Fresse, (2009); Affendy, Asmat-Nizam, \& Farid, (2015); Simiyu, Namusonge \& Sakwa, (2016). However researchers have different arguments about generalizability of findings. Generalization is not accepted by many researchers as the purpose of qualitative, interpretative research, Onwuegbuzie and Leech (2009). Alexandra, (2014) posits that generalizability should become the standard for reporting qualitative and quantitative reports (Alexandra, 2014).

\subsection{Gaps in research}

It is suggested that not all the dimensions of entrepreneurial orientation have a direct or positive effect on business performance (Lumpkin \& Dess, 1996) cited in (Nazri, Wahab, \& Omar, 2015). Thus, it is necessary to assess the relative impact of each dimension of entrepreneurial orientation on performance of SMEs (Kraus, et al., 2012). Besides most studies on DCs and EO had been conducted in developed countries such as US and the UK (Nazri, Wahab, \& Omar, 2015). This underscores the essence of undertaking research in 
developing countries which has different business environment and management style. Moreover, recent studies focused only on a partial analysis of these constructs (Kropp, Linsday, \& Shoham, 2008). This calls for studying all the five dimensions of entrepreneurial orientation in relation to business performance to ascertain whether all dimensions affect performance of SMEs with the same level of intensity amidst moderation by dynamic capabilities.

The link between entrepreneurial orientation and firm performance has remained inconsistent (Karacaoglu, et al., 2012). This calls for further interrogation of what is the exact relationship between EO and business performance of SMEs in order to iron out the inconsistencies. Besides the effect of EO on business performance is not always positive and linear, but contingency-oriented and context-specific, (Sciascia, D'Oria and Bruni, 2014; Wiklund\& Shepherd, 2011). More and more scholars gradually reached a common view on this issue, namely that the relationship between EO and performance is too complex, which is moderated by variables (Lumpkin \& Gregory, 1996; Walter et al., 2006). In entrepreneurship, scholars have emphasized the need to go beyond the investigation of direct correlations between entrepreneurship and performance variables Lumpkin \& Gregory, (1996) cited in Yanlong\&Xiu'e, (2012) to reduce misleading inferences about the entrepreneurship-performance relationship Walter, Auer, \& Ritter, (2006). There are no known studies on the contingent effect of dynamic capabilities on the relationship between EO and business performance of SMEs in Kenya. This warrants an empirical examination of dynamic capabilities as a moderator of the EO performance of SMEs relationship to reduce misleading inferences in the context of developing countries.

\subsection{SMEs in Kenya}

The Micro and Small Enterprises Act No. 55 of 2012 established the Micro and Small Enterprises Authority ending 40-year struggle (1972-2012) for MSME's recognition and mainstreaming of into the formal economy in Kenya (Omukoko, 2016). The SME sector has been widely recognized as an essential driver of economic growth, innovation, employment, and social integration in both developed and developing countries (Neneh \& Smit, 2013). The SMEs subsector are businesses in both formal and informal sectors accounting to more than $74 \%$ of the total persons engaged in employment per year and contributing more than $18.4 \%$ of the country's GDP (Ong'olo \& Awino, 2013).

Despite their significance, past statistics indicate that three out of five businesses fail within the first few months of operation (Kenya National Bureau of Statistics, 2007). There are 7.4 million MSMEs in Kenya; 1.5 million of these businesses are licensed by the 47 county governments and about 5.9 million are unlicensed (KNBS., 2016). This indicates that there is a high number of undocumented businesses operating informally in Kenya. A total of 2,210,472 MSMEs were closed in the last five years including the survey year 2016. With an average age of 3.8 years (KNBS., 2016).This is an index of poor performance of SMEs in Kenya. Article 212 of the Constitution provide for county governments to promote trade development and regulation, including Markets; Trade licenses (excluding regulation of professions); Fair trading practices; Local tourism; and Cooperative societies which imply that county system is instrumental in resource allocation and planning for the development of SMEs in Kenya (Ong'olo \& Awino, 2013).

\section{Literature Review}

\subsection{Empirical review}

Researchers have continued to conceptualize the relationship between entrepreneurial orientation and business performance of SMEs in order to better understand the relationship. Empirical evidences also showed the positive influence of entrepreneurial orientation in various performance measures such as financial performance, growth of the firm and overall business performance (Davis, Bell, Payne, \& Kreiser, 2010; Rauch, Wiklund, Lumpkin \&Frese, 2009).

Ndesaulwa and Kikula, (2016) Examined the Impact of Innovation on Performance of Small and Medium Enterprises (SMEs) in Tanzania: A Review of Empirical Evidence. The study was based on desktop and library research methodology. The literature survey revealed that the studies on innovation and its effect on performance are observed to have concentrated to Western, Middle and Far East and very little empirical evidence is noticeable in Africa. The issue of innovation and how it relate to firm's performance and specially SMEs is thus yet to be exhaustively explored. They posit that based on extant literature review there are no consistent results on whether the innovations altogether influence firms performance. The nature of the empirical results reported in their paper indicates a need for such studies especially in Africa where the research fissure is widely observed in this area. The paper is thus a wakeup call for empirical studies that assess the impact of innovation on SMEs performance in Africa and Tanzania in particular where the studies of this nature are rarely found in the review of literature conducted in this paper. Besides innovation was the only dimension of EO considered in the study living out other dimension which dispatch from the object of the current research intention to bundle all the dimensions and see how they affect performance.

Rauch, et al., (2009). Entrepreneurial Orientation and Business Performance: An Assessment of Past Research and Suggestions for the Future. Extending beyond qualitative assessment, they undertook a meta-analysis exploring the magnitude of the EO-performance relationship and assessed potential moderators affecting 
this relationship. Analyses of 53 samples from 51 studies with an $\mathrm{N}$ of 14,259 companies indicated that the correlation of EO with performance is moderately large $(r=.242)$ and that this relationship is robust to different operationalization's of key constructs as well as cultural contexts. The study adopted both qualitative and quantitative approach. Internal and environmental moderators were identified, and results suggest that additional moderators should be assessed. Recommendations for future research are developed.

Vishal and Safal, (2015) studied Entrepreneurial orientation and firm performance in Indian SMEs: Universal and contingency perspectives Data collected from 1980 Indian SMEs revealed a strong positive linkage between EO and firm performance. Environmental contingencies demand growth and competitive intensity were theorized and found to have a moderating influence on the EO-performance relationship. The study adopted a mixed method approach. The implication is that as much as SMEs embrace Entrepreneurial Orientation there is need also to consider environmental contingencies which moderate the relationship.

Tachia, et al., (2016) in their study on EO-Performance relationships in Reverse Internationalization by Chinese Global Startup OEMs: Social Networks and Strategic Flexibility. Using structural equation modeling, they found that during reverse internationalization, proactivenessis positively related to performance; risk taking is not statistically associated with performance; innovativenessis negatively related to performance. The proactiveness-performance relationship is mediated by Strategic flexibility and moderated by social networking relationships. The dynamic and complex institutional setting, coupled with the issues of overcapacity and rising labor cost in China may explain why their distinctive results occur. This implies a context sensitive nature of entrepreneurial orientation (EO) owing to inconsistencies in finding from other contexts. The adopted a mixed method approaches. This research advances the understanding of how contingent factors (social network relationships and strategic flexibility) facilitate entrepreneurial firms to break down institutional barriers and reap the most from EO.

Gholami and Birjandi, (2016)Studied the effect of market orientation and entrepreneurial orientation on the performance of SMEs. The study adopted descriptive survey design. According to the findings the amount of $\mathrm{T}$ value was more than 2 ( $T$-value $=4.40)$, so the hypothesis with $95 \%$ of confidence not confirmed. These findings denotes that entrepreneurial orientation have significant effect on organizational performance. This implies that Iranian SMEs should capitalize on entrepreneurial orientation to gain high performance. However this study was limited in terms of population used in small and medium-sized enterprises in industrial city of Shiraz, due to geographical constraints cannot generalize the results to the entire population. However, it is suggested that future research should also examine different statistical societies. They further argued that measures used in this study may be less relevant in countries with different environmental and organizational conditions. This all together motivates the need for a similar study in the context of developing countries.

Affendy, et al., (2015) Assessed Effect of Entrepreneurial Orientation on Market Orientation and SMEs Business Performance using Structural Equation Model Approach (SEM). The unit of analysis for this study was the Small Medium Enterprise (SME) in Malaysia and this study deals with each SME manager response as an individual data source. The study was correlational in nature. The findings show that the entrepreneurial orientation does not significantly influence the business performance among SME in Malaysia. Since positive relationship is expected, the non-significance of the relationship between entrepreneurial orientation and business performance controverts the fact that entrepreneurial orientation has been suggested as an integral part of higher business performance and essential attribute of high performing firms (Lumpkin \& Gregory, 1996 ; Lee \& Peterson, 2000). This inconsistency in the findings underpins the need for further research on the relationship between entrepreneurship orientation and the performance of SMEs.

Owoseni and Adeyeye, (2012)conducted a study on the role of entrepreneurial orientations on the perceived performance of small and medium-scale enterprises (SMEs) in Nigeria. The study adopted descriptive survey design. Four hypotheses were tested and the study revealed that innovativeness, risk-taking, and proactiveness jointly predicted organizational performance. Hypothesis one showed that there was a significant relationship between risk-taking and perceived SME performance there was no significant difference between low and high Risk-taking and perceived SME performance (Crit-t $=1.96$, Cal $\mathrm{t}=1.598 ; \mathrm{df}=308, \mathrm{P}>0.5)$. The hypothesis was therefore rejected., hypothesis two showed that risk-taking and innovativeness jointly predicted perceived organizational performance, but proactiveness did not independently predict perceived SME performance where $(F(1,308)=12.815 ; R=.334, R 2=$ $0.103 ; \mathrm{P}<.05)$. About $11 \%$ of the variation was accounted for by the variables. Hypothesis three showed that innovativeness and pro-activeness jointly predicted perceived SME performance and hypothesis four showed that innovativeness and risk-taking jointly predicted perceived SME performance. The finding was that there is no significant interaction effect of Innovativeness and Pro-activeness on SME Performance $(F(3,306)=.622$; $P>.05)$. The hypothesis was therefore rejected. These findings imply that SMEs should pay greater attention to the role of organizational context for different dimensions of entrepreneurship.

Simiyu, Namusonge, \&Sakwa, (2016) Undertook a study on effect of Entrepreneurial Orientation on the Growth of women Micro and Small Enterprises in Trans Nzoia County, Kenya. The study adopted Schumpeter 
innovation theory (Schumpeter, 1942). This research study utilized mixed research design where both qualitative and quantitative approaches were used. The study found out that Entrepreneurial orientation had statistically significant relationship with growth of women MSEs ( $R 2=10.5 \%, F=5.234, P=0.000$ ) at 0.05 level of significance. The dimensions of EO have a collective effect on women owned MSE growth when they are combined and regressed as one single EO variable. This study found that the EO dimensions of innovativeness, risk taking and reactiveness are of equal importance to explain growth of Micro and Small Enterprises. This implies that the use of these dimensions by SME owners would occasion growth of SMEs. These findings also justify the probity of the three dimensions in testing the effect of EO on the performance of SMEs.

Muthee and Karanja, (2014) Sought to establish influence of entrepreneurial orientation on growth of micro and small enterprises in Kerugoya, Kenya. This research study utilized mixed research design where both qualitative and quantitative approaches were used. The objectives of the study were to; find out the effect of innovativeness on growth of Micro and Small Enterprises in Kerugoya, Kenya; to evaluate the extent to which risk taking influences growth of Micro and Small Enterprises in Kerugoya, Kenya; to assess the effect of pro-activeness on growth of Micro and Small Enterprises in Kerugoya, Kenya; and to explore the influence of entrepreneurial managerial competence on growth of Micro and Small Enterprises in Kerugoya, Kenya. The study adopted Schumpeter innovation theory (Schumpeter, 1942). The research adopted a descriptive research design. The study found that the dimensions of EO (innovativeness, risk taking, pro-activeness, and entrepreneurial managerial competence) have a significant positive influence on growth of Micro and Small Enterprises. These findings also imply that SMEs should embrace EO both at individual and firm level to secure maximal performance.

Kamedi, (2016) the role of entrepreneurial orientation on the growth of small and medium enterprises in Nairobi County. The objectives of the study was to; establish the effect of risk taking on SMEs growth, effect of innovativeness on SMEs growth, effect of pro-activeness on growth of SMEs,. The study adopted Schumpeter innovation theory (Schumpeter, 1942), McClelland's Psychological Theory (McClelland, 1961). This study adopted descriptive research design. The findings indicated that risk taking had the highest effect on growth of Nairobi SMEs followed by Pro-activeness, then innovativeness which had the least effect on growth of small and medium enterprises. All the variables were significant as their P-values were less than 0.05.

Açıkdilli and Doğ,an, (2013) in their study on Dynamic Capabilities and Entrepreneurial Orientation in the New Product Development. The study contended that EO affect new product development. They concluded that new product development is an integration of two focal construct dynamic capabilities and entrepreneurial orientation. However these findings were based on the theoretical exposition observations and not statistical evidence.

Mahmood and Hanafi, (2013)Conducted a study on entrepreneurial orientation and business performance of Women-Owned Small and Medium Enterprises in Malaysia: Competitive Advantage as a Mediator. The study tested two hypotheses; there is significant relationship between entrepreneurial orientation and business performance, and competitive advantage mediates the relationship between entrepreneurial orientation and performance. The data was purely quantitative with the use of five Likert scale.The findings revealed that significant relationships exist between entrepreneurial orientation and performance, while competitive advantage was found to partially mediate the entrepreneurial orientation and performance relationships. This means that for performance of SMEs, EO and Dynamic capabilities are capable of mediating or moderation of performance of SMEs as they predict competitive advantage.

Bahram and Azhdar, (2016) assessed technology orientation, dynamic capabilities and SMEs Performance. The study was exploratory research design. The study used survey data from a random sample of 154 small to medium-sized enterprises (SMEs) located in Science Parks in Iran. The results indicated that among three different types of dynamic capabilities, learning capability was the most effective mediator between technology orientation and performance. Given the evidence technology orientation and Dynamic capability is beneficial to business performance of SMEs.

Ari, Kaisu, Saarenketo, and Kalevi, (2005) Entrepreneurial Orientation, Dynamic Capabilities and International Performance by using survey data from 217 manufacturing and service organizations. Their findings indicate that a firm's entrepreneurial orientation and reconfiguring capabilities have an effect on its international performance. These findings provide support to the dynamic capability view of the firm. In this regard by SMEs adopting Entrepreneurial orientation combined with organizational reconfiguring capabilities they would secure competitive advantage and increased business performance.

Augusto, Moeljadi and Rohman, (2014) Effect of Entrepreneurial orientation on business performance of Timor SMEs moderated by Government Policy. The study used explanatory research design. Data Analysis Techniques is Generalized Structured Component Analysis (GSCA). Study result shows that entrepreneurial orientation affect business performance. It means better entrepreneurial orientation can improve performance of small and medium enterprises. Government policy cannot moderate effect of entrepreneurial orientation on business performance. It shows that government policy does not have direct effect and moderating effect to improve SMEs performance. These findings were in contravention with the existing role the government plays 
to promote small businesses through a variety of policies to boost business performance. This implies that a moderator can have a significant or insignificant moderating role on the relationship between EO and business performance.

Kiprotich, Kimosop, Kemboi, and Chepkwony, (2015) Undertook a study on moderating effect of social networking on the relationship between entrepreneurial orientation and performance of small and medium enterprise in Nakuru County, Kenya.The specific objectives were; to determine the effect of risk-taking and pro-activeness on performance of small and medium enterprises and finally to determine the moderating effect of social networking on relationship between entrepreneurial orientation and performance of small and medium enterprises. The study utilized the resource based view theory (Barney 1991). Explanatory research design guided the study.The results indicated that Risktaking, Pro-activeness and Innovativeness were significant in affecting performance of SMEs. Also the results revealed that social networking positively moderates the relationship between risk-taking Pro-activeness and performance of SMEs. This implies that through social networking SMEs can be able to potentiate the effects of EO on business performance. However the SMEs must also orientate themselves to the demands of these social networks through dynamic capabilities.

Rotich, Wanjau and Namusonge, (2015)Moderating Role of Entrepreneurial Orientation on the Relationship between Relationship Lending and Financial Performance of manufacturing SMEs in Kenya. The objective of this study was to determine the moderating effect of entrepreneurial orientation on the relationship between relationship lending and financial performance of manufacturing SMEs. The study used a cross-sectional survey research design. The hypotheses in this study were tested using structural equation modeling and hierarchical moderated multiple regression (MMR). The study found evidence that EO moderates the relationship between relationship lending and financial performance of manufacturing SMEs in Kenya. Further the study determined that relationship lending positively impacts on financial performance of SMEs. This implies that EO is not only a predictor but also a moderator of relationship lending and business performance.

No SME or business organization can operate successfully in isolation without dependence on supportive institutions, variables and factors (Oginni, 2010). In fine SMEs exists and operates within an environment where there is multifaceted interplay in terms of activities as well as networks of relationship between and among human resources, material resources and other systems. In this regard there is need for SMEs to direct their attention to the environment when formulating their strategies for adapting to the dynamics in the business environment to facilitate their survival, growth and profit motives. These all together calls for Entrepreneurial orientation by SMEs which would be contingent upon other factors to stimulate performance. This study looks at the moderating role of Dynamic Capabilities on the relationship between EO and organization performance. This is premised on the recommendations of Rauch, Wiklund, Lumpkin, \&Fresse, (2009) that there is need for studying other moderators on the relationship between EO and business Performance of SMEs.

\section{Conceptual framework}

This study conceptualizes the relationship between dynamic capabilities, Entrepreneurial orientation and business performance. Entrepreneurial Orientation (EO) is often mentioned as an antecedent of business performance (Kraus, Ringtering, Hughes, \& Hosman, 2012). According to Voss, Voss, \& Moorman, (2005); Pearce, Fritz, \& Davis,( 2010) EO as a firm-level disposition to engage in behaviors reflecting risk-taking, innovativeness, proactiveness, autonomy, and competitive aggressiveness that lead to change in the organization or marketplace. entrepreneurial orientation can be measured interms of risk-taking, innovativeness, proactiveness and competitive aggressiveness.

Risk-taking is uncertainty that follows an entrepreneurial behavior. Entrepreneurial behavior involves investing a significant proportion of resources to a project prone to failure (Kraus, et al., 2012). Risk taking is a dominant attribute of entrepreneurship as the higher the risk-taking orientation, the higher a firm's profitability and growth (Wambugu, et al., 2015). Risk taking can be measured in terms of financial risks, market risks and operation risks (Larisa \& Margarita, 2015).

Innovativeness refers to a firm's behavior to generate new ideas leading to new or improved processes, products, or services (Rauch, et al., 2009). Innovativeness is also related to creativity which is a source of ideas that can lead to innovation of products, services, processes, markets or technology which leads to increased business performance (Okeyo, Gathungu, \& K'Obonyo, 2016). Innovation can be measured in terms of new technology,products and markets (Giudici\&Reinmoeller, 2013; Milovanovic\&Wittine, 2014).

Proactiveness refers to processes which are aimed at "seeking new opportunities which may or may not be related to the present line of operations, introduction of new products and brands ahead of competition and strategically eliminating operations which are in the mature or declining stages of the life cycle" Venkatraman (1989) cited in (Zhongfeng, En, \& Dong, 2013). There is a direct positive relationship between the EO dimension of proactiveness and SME business performance (Kraus, et al., 2012). Proactivenes can be measured interms of opportunity recognition, market responsiveness, first-mover (Lumpkin \&Dess, 2001; Kropp, Lindsay, \&Shoham, 2008; Kusumawardhani, McCarthy, \&Perera, 2009). 
Competitive aggressiveness is the intensity of the firm's to improve their position to outdo and overtake their competitors in the market (Lumpkin \& Dess, 1996) cited in (Azlin, et al., 2014). Competitive aggressiveness is positively connected to business performance under most circumstances though context dependent (Sonja, 2017). Competitive aggressiveness comes in the form of competitive attack, which consists of a sequence of competitive actions. Ferrier (2001) distinguishes four dimensions of competitive attack: volume, duration, complexity and unpredictability (Becem, 2015). The study measures competitive aggressiveness based on the dimensions of competive attack which include attack volume,attack duration attack complexity and attack unpredictability.

Dynamic capability plays an important role in an organization as it underscores the accumulation of capabilities embedded in a firm and it is directly associated with its performance (Hsu \& Wang, 2012). There is a variation in the previous research findings in terms of the relationship between EO and business performance. As a result, researchers began to seek internal and external factors that mediate the relationship between EO and firm performance rather than measuring the direct link between them eg (Lumpkin.G.T. \&Dess, 2001; Li, Huang, \& Tsai, 2009; Wang., 2008;Alegre \&Chiva, 2013 ). Therefore this study, interrogates the moderating effect of dynamic capabilities on the effect of EO on business performance of SMEs. Dynamic capabilities can measured in terms of three dimensions of sensing, integration, and reconfiguration adopted from (Teece, 2014)

In measuring business or firm performance of small and medium enterprises, both subjective and objective measures can be used. Objective measures are obtained from firm's annual accounts or financial records while subjective measures involve seeking the perception of owner/managers on overall performance relative to that of competitors during a certain time period (Idar \& Mahmood, 2011). Objective measures are difficult to obtain because owner/managers are generally conservative and unwilling to release actual financial information to outsiders (Chao \& Spillan, 2010) (Wang \& Poutziouris, 2010). This justifies the use of subjective measures of firm performance which is in consistence with empirical studies (Idar \& Mahmood, 2011). In extant empirical works, many indicators tend to be used. 'Performance' is regularly measured in one or a combination of the following three ways: perceived financial, perceived non-financial and archival financial (Rauch, et al., 2009). In this regard this study adopted subjective measures of business performance which includes sales growth, employee growth and profitability relative competitors adopted from (Wambugu, Gichira, Wanjau, \&Mung'atu, 2015).

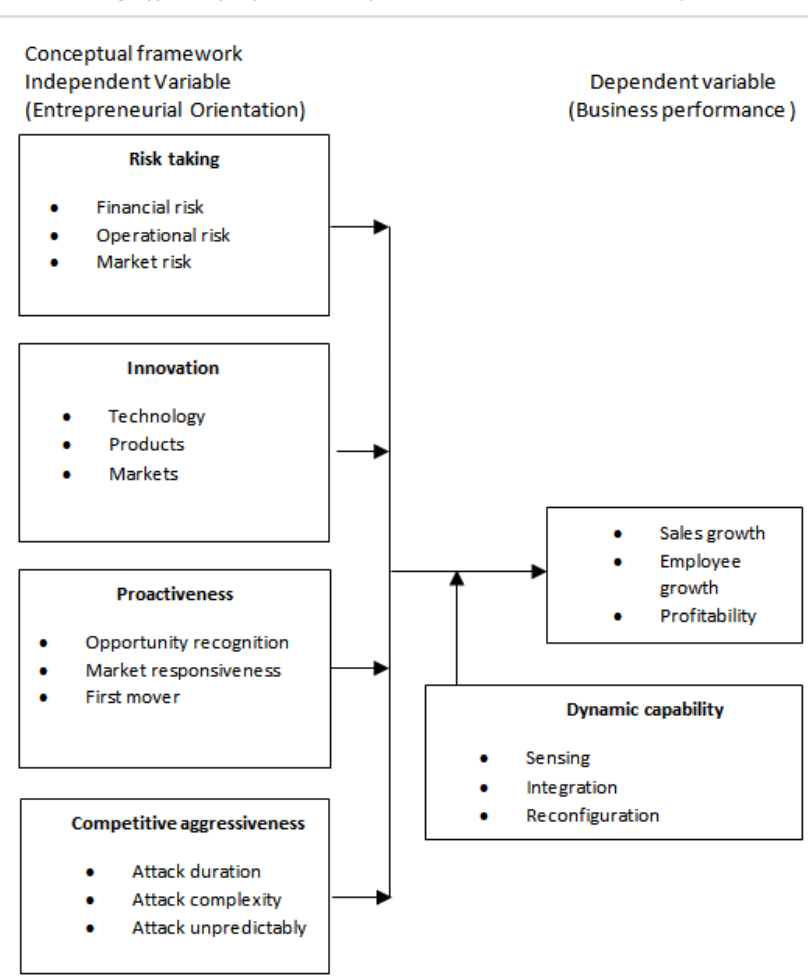

\section{Discussion}

SMEs performance remains essential because of their potential to generate jobs and capacity to catalyze economic growth. However from existing literature they are beset by incessant failures in performance owing to entrepreneurial incompetence. This provides a wakening call for them to embrace Entrepreneurial orientation and Dynamic capabilities as a recipe for performance. This argumentation is premised on Schumpeter theory of innovation and Teeces Dynamic capability theory. However literature points out limitations and inconsistencies in outcomes of these theories.

Schumpeter's theory of innovation posits that innovation is an inordinate instrument of entrepreneurship for gaining competitive advantage to increase their capacity to generate wealth. This position obscures the fact that there are other factors such as economic and social factors which need to be integrated with innovation to occasion high performance of SMEs. Innovation requires some magnitude of monetary and non-monetary investments besides social networking whose absence has been incriminated for the failure of most enterprises. On the same vein lack of dynamic capabilities has been pointed out to be a source of failure of SMEs in dynamic markets which no market is an exception of. Conversely when SMEs are ingrained with dynamic capabilities they become prone to traps in their existing competencies making them incompetent to respond to environmental changes in order to realize maximal performance. However owing to DCs significant effect when effectively implemented as opined by(Helfat, et al., 2007; Wang and Ahmed, 2007; Mwangi and Gathungu, 2012). Thus, SMEs are under obligation to embrace it in the face of dynamic environment. 
Dynamic capabilities can enhances SMEs capacity to develop new products and processes in response to changing circumstances while Entrepreneurial orientation involves activities like innovation, searching for the opportunity and effectively utilizing resources. Hence, the integration of both dynamic capabilities and entrepreneurial orientation owing to their assimilation of entrepreneurial resources in generating new ideas for the creation of new products and processes cannot be gainsaid. In this regard this study draws from the Schumpeter theory and Dynamic capabilities theory to strive to identify which dimensions of Entrepreneurial orientation can affect performance of SMEs by a significant moderation of dynamic Capabilities in the Kenyan context.

Although the relationship between Entrepreneurial orientation and business performance has been researched. The effect of EO on performance is not always positive and linear, but contingency-oriented and context-specific (Sciascia, D'Oria and Bruni, 2014; Wiklund\& Shepherd, 2011). Specifically, the EOperformance relationship won't remain static; the impact of EO on firm performance may differ if in various industrial settings, development stages, or under market turbulence and financial crisis (Fuentes-Fuentes, Bojica, \& Ruiz-Arroyo, 2015; Jones, Coviello, \& Tang, 2011). Hence, despite the increasing attention, greater insights into the EO- performance linkages, there is need to furthering research on this theme in different industrial settings for better understanding of the relationship. The implications of this are that we may get different results in different settings occasioned by prevailing parameters in the various business environments.

Interestingly a handful of studies on relationship between EO and performance of SMEs have revealed no significant relationship, (Affendy, et al., 2015), sometimes moderately large significant relationship (Rauch, et al., 2009) and positive significance,(Gholami and Birjandi, 2016; Simiyu, et al., 2016; Muthee and Karanja, 2014; Vishal and Safal, 2015). Inconsistencies have also been revealed on the effect of different dimensions of EO on business performance, (Ndesaulwa\&Kikula, 2016; Udin\& Bose, 2014; Tachia, et al., 2016; kamendi, 2016). These inconsistencies imply that results from past studies could not be generalized. All these inconsistencies in findings from the afformentioned studies provides knowledge gap to be filled by future studies in order to clarify the exact effect of EO on firm performance.

The studies reviewed related to EO and performance have been conducted in non-African countries ( Rauch, et al., 2009; Gholami and Birjandi, 2016; Affendy, et al.,2015;Vishal and Safal, 2015 ; Tachia, et al., 2016; Udin and Bose, 2014).In African countries, (Ndesaulwa \& Kikula, 2016; Owoseni \& Adeyeye, 2012 ) in Kenya (Simiyu, et al., 2016; Muthee \& Karanja, 2014). All the studies points to the fact that entrepreneurial orientation has an effect on SMEs performance. However the results cannot be generalized because the definition of SMEs differs from country to country and especially in western countries and developing countries like Kenya. Besides measures used in this study may be less relevant in countries with different environmental and organizational conditions. Finally EO is context-specific. Generalization of EO and firm performance amongst studies in the same country is not possible because of differences in industrial settings.

Most of the reviewed studies were limited in the variables that were considered for entrepreneurial orientation; (Kamedi, 2016; Simiyu, et al., 2016; Owoseni and Adeyeye, 2012; Tachia, et al., 2016) considered three variables; innovativeness, risk taking and pro-activeness. Autonomy and Entrepreneurs managerial competence was studied by Udin\& Bose, (2014); Mutheeand Karanja, (2014) respectively besides innovativeness, risk taking and pro-activeness. From literature, EO has five dimensions namely risk taking, pro-activeness, innovations, autonomy and aggressive competition, Rauch, et al., (2009). Hence the results of the reviewed studies failed to exhaustively explore the effect of all dimensions bundled together on EO on SMEs performance since few variables were considered. This provides a variable gap to be filled further studies.

There are few studies that have determined moderating effect of dynamic capabilities on entrepreneurial orientation and SMEs performance. Açıkdilli and Doğ,an, (2013) in their study on Dynamic Capabilities and Entrepreneurial Orientation in the New Product Development contend that DC and EO contribute to new product development however the study was based on observation without statistical backing. Other studies reviewed showed other moderators on the relationship between EO and business performance for instance eg Augusto, et al., (2014) Studied moderating effect of government policy on Entrepreneurial orientation and SMES performance where results were not significant hence no mediation which controverts the perceived role of the government in setting regulation which can moderate business performance. Mahmood and Hanafi (2013) sought to establish mediating effect of competitive advantage on entrepreneurial orientation and performance of Women-Owned SMEs in Malaysia which revealed significant moderation.

Bahram, et al., (2016) Assessed mediating effect of dynamic capabilities on technology orientation and SMEs Performance. Kiprotich, et al., (2015), undertook a study on moderating effect of social networking on the relationship between entrepreneurial orientation and performance of SMEs in Nakuru County the study revealed significant effect of the moderators. The review however revealed that EO can play a role of both predictors and moderators for firm performance as seen in Kiprotich, et al., (2015); Mahmood \& Hanafi, (2013); Açıkdilli \& Doğ,an, (2013) and Ari, et al., (2005); Rotich, et al.,(2015) as moderator. DC can also moderate relationship between EO and performance Açıkdilli \& Doğ,an, (2013) while as predictor of firm performance 
Bahram \& Azhdar, (2016). This explained by the fact that Dynamic capabilities can also manifest through characteristic such as entrepreneurial orientation, human capital and social capital to predict the business performance of SMEs.

\section{Conclusions}

Schumpeter theory of innovation and dynamic capabilities gives credence to the conceptualization of the moderating effect of DC on the relationship between EO and business performance of SMEs. This is explained by the synergistic effect of both the theories in securing maximal business performance. EO and DC are context specific hence their effect on business performance may vary from industry to industry but what remains clear is that effective integration and implementation of EO and DC would help the organization secure competitive advantage in the face of dynamic business environment foster high business performance of SMEs. However organizations can take different paths yet possibly end up with similar dynamic capabilities. Alternatively, organizations can possess similar capability yet perform differently. Moderation effects of DCs differ in different cultural contexts.

There are mixed results in the relationship between EO and business performance, some significant other insignificant as highlighted in the discussion which warrants further scientific interrogation on their relationship. Beside literature review reveals a dearth of studies which have been done on the moderating role of $D C$ on the relationship between EO and business performance of SMEs in the context of developing countries. These altogether motivates the need to design studies on moderating role of DC on the relationship between EO and business performance of SMEs in developing countries fill in the existing knowledge gaps in literature.

\section{References}

[1]. Açıkdilli, G., \& D.,. (2013). Dynamic Capabilities and Entrepreneurial Orientation in the New Product Development. International Journal of Business and Social Science , 4 ( 11).

[2]. Adomako, S. (2017). The moderating effects of adaptive and intellectual resource capabilities on the relationship between entrepreneurial orientation and financial performance. ResearchGate, DOI: 10.1142/S1363919618500263.

[3]. Affendy, A., Asmat-Nizam, A., \&Farid, M. (2015). Entrepreneurial Orientation Effects on Market Orientation and SMEs Business Performance - A SEM Approach. Retrieved from Available at https://www.researchgate.net/ publication/273755737 assessed 24/11/2017

[4]. Alegre, J., \&Chiva, R. (2013). Linking Entrepreneurial Orientation and Firm Performance: The Role of Organizational Learning Capability and Innovation Performance. Journal of Small Business Management, 51(4), 491-507.
[5]. Alexandra, G. (2014). Is qualitative research generalizable. Journal of community positive practices , XIV(3), 114-124.

[6]. Aluisius, H. P., \& Rosli, M. (2015). Entrepreneurial orientation and firm performance: How can micro small and medium-sized enterprises survive environmental turbulence? Pacific Science Review B: Humanities and Social Sciences, 1(2) , 85-91.

[7]. Ari, J., Kaisu, P., \& Saarenketo, K. K. (2005). Entrepreneurial Orientation, Dynamic Capabilities and International Performance. Journal of International Entrepreneurship 3(3), 223-243.

[8]. Ari, J., Kaisu, P., Saarenketo, S., \&Kalevi, K. (2005). Entrepreneurial Orientation, Dynamic Capabilities and International Performance. Journal of International Entrepreneurship , 3( 3) , 223-243.

[9]. Auger, P., BarNir, A., \& Gallaugher, J. M. (2003). Strategic orientation, competition", and Internet -based electronic commerce: electronic commerce. Information Technology and Management , 4, (2), 139.

[10]. Augusto, C. S., Moeljadi,F., \&Rohman, S. (2014). Effect of Entrepreneurial orientation on business performance moderated by government policy. International Journal of Business and Management Invention , 3 ( 8).

[11]. Azlin, S., Amran, R., Afiza, A., \& Zahariah, M. Z. ( 2014 ). The Impact of Entrepreneurial Orientation on Business Performance: A Study of Technology-based SMEs in Malaysia. Social and Behavioral Sciences, $130,46-53$.

[12]. Bahram, R. H., \& Azhdar, K. (2016). Technology Orientation, Dynamic Capabilities and SMEs Performance. Strategic Management Quarterly , 4,(1) 41-60.

[13]. Barney, J., \& Arikan, A. M. (2001). The resource based view: origins and applications. NewYork: Blackwell Publishing Ltd.

[14]. Baron, S., \& Harris, K. (2010). Toward an understanding of consumer perspectives on experiences. Journal of Services Marketing , 24(7), 518-531.

[15]. Barreto, I. ( 2010). Dynamic capabilities: A review of past research and an agenda for the future. Journal of Management , 36(1), 256-280.

[16]. Bayati, A., \&Taghavi, A. (2007). The impacts of acquiring ISO 9000 certification on the performance of SMEs in Tehran. The TQM Magazine, , 19 (2), 140-149.

[17]. Becem, B. (2015). The impact of competitive aggressiveness on the relative supply market position of factor-market rivals. Unpublished thesis University of Twente.

[18]. Bellner, B., \& Maclean, D. ( 2015 ). Dynamic Managerial Capabilities and Competitive Advantage. Retrieved from https://www.researchgate.net/publication/286524879_Dy namic_Managerial_Capabilities_and_Competitive_Advanta ge assessed on 23/11/2017

[19]. Chao, M., \& Spillan, J. (2010). The journey from market orientation to firm performance. A comparative study of US and Taiwanese SMEs. Management Research Review, 33(5), 472-483.

[20]. Chmielewski, D. A., \&Paladino, A. (2007). Driving a resource orientation: reviewing the role of resource and capability characteristics. Management Decision , 45(3).

[21].Covin, J. G., Slevin, D. P., \& Schultz, R. L. (1994). Implementing strategic missions: Effective strategic, structural, and tactical choices. . Journal of Management Studies, 31(4), 481- 503.

[22]. Danneels, E. (2002). The dynamics of product innovation and firm competences. Strategic Management Journal , 23, 1095-1121. 
[23]. Danneels, E. (2002). The dynamics of product innovation and firm competences. Strategic Management Journal , 23, 1095-1121.

[24]. Darshana, M. (2015). A dynamic capabilities perspective of internationalization and performance of SMES in South Asia: A Conceptual Framework. Research Gate .

[25]. Davis, J., Bell, R. G., Payne, G., \&Kreiser, P. (2010). Entrepreneurial Orientation and Firm Performance: The Moderating Role of Managerial Power,. American Journal of Business , 25(2), $41-54$.

[26].DESS, G. G., \& LUMPKIN, G. T. (2005). The role of entrepreneurial orientation in stimulating effective corporate entrepreneurship. . The Academy of Management Executive , 19( 1) 147-156,

[27]. Dimitratos, P., Lioukas, S., \& Carter, S. (2004). The relationship between entrepreneurship and international performance: The importance of domestic environment. . International Business Review , 13,19-41.

[28]. Drnevich, P. L., \&Kriauciunas, A. P. (2011). Clarifying the conditions and limits of the contributions of ordinary and dynamic capabilities to relative firm performance. Strategic Management Journal , 32(3).

[29]. Drucker, P. (1985). Innovation and entrepreneurship . New York: Happer and Row.

[30]. Easterby-Smith, M., Thorpe, R., \& Jackson, P. (2008) Management Research. London: Sage.

[31]. Eggers, F., Kraus, S., Hughes, M.,Laraway, S., \&Syncerski, S. (2013). Implications of customer and entrepreneurial orientations for SME growth. Management Decision , 51(3) 524-546.

[32]. Eisenhardt, K. M., \& Martin, M. (2000). Dynamic capabilities: what are they . Strategic Management Journal , 21, 1105-1121.

[33]. Fainshmit, S., Pezeshikan, A., Fraizer, M., Nair, A., \&Markownski, E. (2016). Dynamic Capabilities and Organizational Performance: A Meta-Analytic Evaluation and Extension. Journal of management studies , 53 (8) $1348-1380$.

[34]. Fairoz, F., Hirobumi, T., \& Tanaka, Y. (2010) Entrepreneurial Orientation and Business Performance of Small and Medium Scale Enterprises of Hambantota District Sri Lanka. Asian Social Science , 6 (3).

[35]. Fang, N., Yuli, Z., \&Hongzhi, X. (2009). Acquisition of resources, formal organization and entrepreneurial orientation of new ventures. Journal of Chinese Entrepreneurship , 1 (1),40-52.

[36]. Fin Mark. (2010). Fin Scope South Africa Small Business Survey. Retrieved from Available at http://www.finmark.org.za/wpcontent/ assessed at $5 / 7 / 2017$

[37]. Frank, J. (2010). Perceived risks and choices in entrepreneurs" new venture decisions. Journal of Business Venturing, 15, 305.

[38]. Fuentes-Fuentes, M., Bojica, A., \& Ruiz-Arroyo, M. ( 2015) Entrepreneurial orientation and knowledge acquisition: effects on performance in the specific context of womenowned firms.. International Entrepreneurship and Management Journal. , 11:695-717.

[39]. Gamage, P., \& Weerakoon, W. (2017). Relationship between Entrepreneurial Knowledge and Strategic Orientation. International Journal of Scientific and Research Publications, , 7( 11)

[40]. Garcia, R., \& Calantone, R. (2002). A critical look at technological innovation typology and innovativeness terminology: a literature review. Journal of Product Innovation Management , $19,110-132$.
[41].Gathungu, J., \&Mwangi, J. (2012). Dynamic Capabilities, Talent Development and Firm Performance. DBA Africa Management Review, , 2 ( 3), 83-100.

[42]. George, G., Wood, D. R., \& Khan, R. ( 2001). Networking Strategy of Boards: Implications for Small and MediumSized Enterprises. . Entrepreneurship-and-RegionalDevelopment , 13(3), 269-285.

[43]. Gholami, S., \&Birjandi, M. (2016). Studied the effect of market orientation and entrepreneurial orientation on the performance of SMEs. Journal of Current Research in Science, (1): 361-369.

[44]. Giudici, A., \&Reinmoeller, P. (2013). Sensing together: anexploration of the support of network intermediaries to firms' and entrepreneurs' search for new opportunities. Unpublished Thesis, Cranfield University .

[45]. Grande, J., Madsen, E. L., \&Borch, O. J. (2011). The relationship between resources, entrepreneurial orientation and performance in farm-based ventures. Entrepreneurship and Regional Development , 23(3-4) 89111.

[46]. Hamel, G., \& Coimbatore, K. P. (2010). Competing for the Future. Cambridge: MA: Harvard Business School Press.

[47]. Hart, S. L. ( 1992). An integrative framework for strategymaking processes. . Academy of Management Review, 17(2), 327-351.

[48]. Helfat, C. E., Finkelstein, S., Mitchell, W., Peteraf, M. A., Singh, H., Teece, D. J., et al. (2007). Dynamic capabilities: Understanding strategic change in organizations. Malden, MA: Blackwell.

[49]. Helfat, C., \& Peteraf, M. (2003). The dynamic resourcebased view: capability lifecycle,. 24(10), 997-1010.

[50]. Herber, S., \& Reichel, A. (2007). The cumulative nature of the entrepreneurial process: The contribution of human capital, planning and environmental resources to smal venture performance. . Journal of Business Venturing , 22, 119-145

[51].Herrington, M., Kew, J., \& Kew, P. (2010). Tracking Entrepreneurship in South Africa: A GEM Perspective. Retrieved from Available at: http://www.africanentrepreneur.com/images/library/pdf/ GEM\%20SA\%202009\%20-\%20Tracking\%

[52]. Hitt, M. A., Ireland, R. D., Camp, S. M., \& Sexton, D. L. (2001). Strategic entrepreneurship: entrepreneurial strategies for wealth creation. Strategic Management Journal , 22(6-7), 479-491.

[53]. Hsu, L. C., \& Wang, C. H. (2012). Clarifying the effect of intellectual capital on performance: The mediating role of dynamic capability. British Journal of Management , 23(2), 179-205.

[54]. Hult, G., Hurley, R., \& Knight, G. (2004). Innovativeness: Its antecedents and impact on business performance. Industrial Marketing Management, , 33 429-438.

[55]. Hwan-Jin, K. (2014). Reconciling entrepreneurial orientation and dynamic capabilities. Retrieved from https://www.researchgate.net/.../Hwan_Jin...Reconciling_E ntrepreneurial_Orientation . assesed on 23/11/2017

[56].Idar, R., \&Mahmood, R. (2011). Entrepreneurial \& market orientation relationship to performance: The SME Perspective. Interdisciplinary Review of Economics and Management , 1(2), 1-24.

[57].Jones, M., Coviello, N., \& Tang, Y. (2011). International Entrepreneurship research (1989-2009): A domain ontology and thematic analysis. Journal of Business Venturing , 26(6):632-659. 
[58]. Kamedi, B. (2016). the role of entrepreneurial orientation on the growth of small and medium enterprises in Nairobi County. Unpublished Research thesis submitted to University of Nairobi.

[59]. Karacaoglu, K., Bayrakdaroglu, A., \& San, F. (2012). The impact of corporate entrepreneurship on firms' financial performance: Evidence from Istanbul Stock Exchange Firms. International Business Research , 6(1): 163-175.

[60]. Kiprotich, S., Kimosop, J., Kemboi, A., \&Chepkwony, P. (2015). Moderating effect of social networking on the relationship between entreprenual orientation and performance of small and medium enterprise in Nakuru County, Kenya. European Journal of Small Business and Entrepreneurship Research , 3(2), 38-52.

[61]. KNBS. (2007). Kenya National Bureau of Statistics Informal Manufacturing Activities in Kenya. Retrieved from www.afdb.org/fileadmin/uploads/afdb/documents/.....pdfa ssesed on $5 / 12 / 17$

[62]. KNBS. (2016). Kenya National Bureau Of Statistics;Micro, Small And Medium Establishment (MSME) SURVEY. Nairobi: Kenya National Bureau of Statistics.

[63]. Kraus, S., Frese, M., Friedrich, C., \& Unger, J. (2005) Entrepreneurial orientation: a psychological model. European Journal of Work and Organizational, 14(3), 315344.

[64]. Kraus, S., Ringtering, J., Hughes, M., \&Hosman, V. ( 2012). Entrepreneurial orientation \& the business performance of SMEs: A quantitative study from The Netherlands. Review of Managerial Science , 6, 161-182.

[65]. Kreiser, P. M., \& Davis, J. (2010). Entrepreneurial Orientation and Firm Performance: The Unique Impact of Innovativeness, Proactiveness, and Risk-taking. Journal of Small Business \& Entrepreneurship , 23,(1).

[66]. Krishna, M., Annie, T., Choo, C., Chang, S., Jonathan, T. Y., \& Tan, K. L. (2012). A Study on Factors Affecting the Performance of SMEs in Malaysia. International Journal of Academic Research in Business and Social Sciences , 2(4).

[67].Kropp, F., Lindsay, N. J., \& Shoham, A. (2008) Entrepreneurial Orientation a International Entrepreneurial Business Venture Startup. International Journal of Entrepreneurial Behaviour \& Research , 14, 102 - I 17.

[68]. Kropp, F., Linsday, N. J., \&Shoham, A. (2006). Entrepreneurial, Market and Learning Orientations and International Entrepreneurial Business Venture performance in South African firms. International marketing Review , 23 (5) 504-523.

[69]. Kusumawardhani, A., McCarthy, G., \&Perera, N. (2009). Framework of entrepreneurial orientation and networking: a study of SMEs performance in a developing country. Proceedings of the Australian and New Zealand Academy of Management Conference (p. 1 16). Adelaide, Australia: Australian and New Zealand Academy.

[70]. Lant, T. K., Milliken, F., \&Batra, B. (1992). The role of managerial learning and interpretation in strategic persistence and reorientation: an empirical exploration', . Strategic Management Journal of management , 13, 585608.

[71]. Larisa, B., \& Margarita, B. (2015). Business Risk Management : Features and problem in small and medium sized trading and manufacturing enterprises. European scientific Journal , 2 , 1857-7881.

[72].Lee, S., \& Peterson, S. (2000). Culture, entrepreneur orientation, and global competitiveness. Journal of World, 35: 401-416.
[73]. Leko-Simi, M., \&Horvat, J. (2006). Risk Taking Propensity and Export Performance of Croatian Exporters. Managing Global Transitions , 4 (4), 313-326.

[74].Levitt, B., \& March, J. (1988). Organizational learning. Annual Review of Sociology , 14,319-340.

[75]. Li, Y., Huang, J., \& Tsai, M. (2009). Entrepreneurial orientation and firm performance: the role of knowledge creation process. Industrial marketing management, 38, 440-449.

[76].Lumpkin, G., \& Dess, G. (1996). Clarifying the entrepreneurial orientation construct and linking it to performance. . Academy of management review, 21(1), 135-172.

[77].Lumpkin.G.T.,\& Dess, G. (2001). “Linking Two Dimensions of Entrepreneurial Orientation to Firm Performance: The Moderating Role of Environment and Industry Life Cycle". Journal of Business Venturing , 16: 429-451.

[78]. Mahmood, R., \&Hanafi, N.. (2013). Entrepreneurial Orientation and Business Performance of Women- Owned Small and Medium Enterprises in Malaysia: Competitive Advantage as a Mediator. International Journal of Business and Social Science, 4(1).

[79]. Maragia, I. (2008). Factors that determine entrepreneuria behaviour in micro and small enterprises (MSEs) in Kenya. Reviews from LibraryThing.com:ISBN: 9966909761

[80]. Marta, P., \& Jean, M. (2015). New challenges in entrepreneurship and finance examining prospects for sustainable business development and performance, innovation and economic growth. Springer

[81]. Mekeown, M. (2008). The truth about innovation . Pearson. Financial Times. ISBN.

[82]. Mentzer, J. (2007). The role of logistics in new product development. Journal of Business Logistics , 28(1), 83-110.

[83]. Milovanovic, B., \&Wittine, Z. (2014). Analysis of Environment's Moderating Role on the Entrepreneurial Orientation and Business Performance Relationship among Italian Small Enterprises External environment may be hostile. International Journal of Trade, Economics and Finance , 5, (3).

[84]. Mohammed, S. (2014). Entrepreneurial orientation and financial performance of Nigerian SMEs: the moderating role of environment. Unpublished Phd Thesis Universiti Malaysia Sarawak.

[85]. Murphy, G. B., Trailer, J. W., \& Hill, R. C. (, 1996,). Measuring performance in entrepreneurship research. Journal of Business Research , 36( 1) 15-23.

[86]. Murphy, P. (2011). A $2 \times 2$ Conceptual Foundation for Entrepreneurial Discovery Theory. Willy Online Library.

[87]. Muthee, A., \& Karanja, N. (2014). Influence of entrepreneurial orientation on growth of micro and small enterprises in Kerugoya, Kenya. European Journal of business management, 1(11).

[88]. Mwangi, J., \& Gathungu, J. (2012). Dynamic Capabilities, Talent Development and Firm Performance. DBA Africa Management Review , 2 ( 3), 83-100.

[89]. Mwangi, K. J. (2016). Drivers of competitive advantage and performance of commercial banks in Nairobi County Kenya. Unpublished thesis Kenyatta University

[90]. Mwangi.J.,\& Kiiru, D. (2017). Initial Conditions, Dynamic Capabilities and Performance. Retrieved from Journals.spu.ac.ke/index.php/test/article/download/56/44

[91]. Nazri, A., Wahab, K., \& Omar, A. (2015). The Effect of Entrepreneurial Orientation Dimensions on Takaful Agency's Business Performance in Malaysia. Jurnal Pengurusan , 45, 83 - 94. 
[92]. Ndesaulwa, A. P., \&Kikula, J. (2016). The Impact of Innovation on Performance of Small and Medium Enterprises (SMEs) in Tanzania: A Review of Empirical Evidence. Journal of Business and Management Sciences , 4(1) 1-6.

[93]. Neneh, B., \&Smit, A. (2013). Will promoting more typical SME start-ups increase job creation in South Africa? African Journal of Business management , 7(31), 30433051.

[94]. Oginni, B. (2010). Business Organic Management,.Somolu Lagos: ,Shecom Press Ltd. .

[95]. Okeyo, W., Gathungu, J. M., \& K'Obonyo, P. (2016). Entrepreneurial Orientation, Business Development Services, Business Environment, and Performance: A Critical Literature Review. European Scientific Journal, 12 ,(28) ISSN: $1857-7881$.

[96]. Okpara, J. O. (2009). Strategic choices, export orientation and export performance of SMEs in Nigeria. . Management Decisions , 47(8), 1281-1299.

[97]. Omukoko, S. (2016). Release of new SME sector survey data long overdue. Retrieved 05 22, 2018, from https://www.businessdailyafrica.com/analysis/Release-ofnew-SME-sector-survey-data-long-overdue/5395483485204-In9d6mz/index.html

[98]. Ong'olo, D., \&Awino, S. ( 2013). Small and Medium Enterprises and Devolved Government System: an Assessment of the Regulatory and Institutional Challenges Affecting the SMEs Development in Kenya. CUTS Centre for International Trade Economics and Environment, ICBE-RF Research Report N0. 71/13.

[99]. Owoseni, O., \& Adeyeye, T. C. (2012). The Role of Entrepreneurial Orientations on the Perceived Performance of Small and Medium-Scale Enterprises (SMEs) in Nigeria. International Business and Management, $5(2), 152-158$.

[100]. Panzano, P. C., \& Billings, R. S. (2005). An organizational level test of a partially mediated model of risky decisionmaking behavior. Retrieved from", Available from Http://www.dssincorporated.com/Research/RiskyDecision/ risky.html. (Retrieved 5/11/17

[101]. Pearce, J., Fritz, P., \& Davis, P. (2010). Entrepreneurial orientation and the performance of religious congregations as predicted by rational choice theory. Entrepreneurship Theory and Practice , 34(1), 219-248.

[102]. Piore, M. (2007). "A Critical View of Schumpeter 'Theory' of Innovation". Retrieved from https:// economics.mit.edu/files/3099 assessed on 22/11/2017

[103]. Rauch, A., Wiklund, J., Frese, M., \& Lumpkin, G. (2005). Entrepreneurial Orientation and Business Performance: Cumulative Empirical Evidence. Retrieved 03 21, 2018, from

https://fusionmx.babson.edu/entrep/fer/FER_2004/webcontent/Section\%20VI/P1/VI-P1_Text.html

[104]. Rauch, A., Wiklund, J., Lumpkin, G., \&Fresse, M. (2009). Entrepreneurial Orientation and Business Performance: An Assessment of Past Research and Suggestions for the Future. Willy Online library, Volume 33, Issue 3 Pages 761787.

[105]. (RoK). (2015). Republic of Kenya Minimum consolidated wage guidelines-1st may 2015. Ministry of labour and East African affairs. Nairobi, Kenya: Government printer.

[106]. Rotich, K. A., Wanjau, L., K., \&Namusonge, G. (2015). Moderating Role of Entrepreneurial Orientation on the Relationship between Relationship Lending and Financial
Performance of manufacturing SMEs in Kenya. European Journal of business management , $7,(18)$.

[107]. Rukevwe, J. (2015). Effect of Innovation on the Performance of SMEs Organizations in Nigeria, Management. Scientific and academic publshing , 5 (3),9095.

[108]. Sanket, S. (2017). Criticisms of Schumpeter's Theory of Economic Development. Retrieved from http://www.economicsdiscussion.net/schumpeterstheory/criticism/criticisms-of-schumpeters-theory-ofeconomic-development/13005 assesed on 22/11/2017

[109]. Schumpeter, J. (1934). The theory of economic development. Boston: Harvard university press.

[110]. Sciascia.S.,D'Oria, L., Bruni, M., \& B., L. (2014). Entrepreneurial orientation in low- and medium-tech industries: The need for absorptive capacity to increase performance. European Management Journal. 2014; 32(5):761-769. , 32(5),761-769.

[111]. Sharmilee, S., \& Muhammad, H. ( 2016). Factors affecting the performance of small and medium enterprises in KwaZulu-Natal, South Africa. Problems and Perspectives in Management , 14( 2).

[112]. Simiyu, F. M., Namusonge, G., \&Sakwa, M. (2016). Effect of Entrepreneurial Orientation on the Growth of women Micro and Small Enterprises in Trans Nzoia County, Kenya. Journal of Research in Business, Economics and Management (JRBEM) , 7( 4).

[113]. Singh, R. K., Garg, S. K., \& Deshmukh, S. G. (2008). Strategy development by SMEs for competitiveness: a review. Benchmark. An International Journal , 15(5), 525547.

[114]. Singh, R., Garg, S., \& Deshmukh, S. (2010). The competitiveness of SMEs in a globalized economy: Observations from China and India. Management Research Review , 33 (1),54-65.

[115]. Sitkin, S. B., See, K. E., Miller, C. C., Lawless, M. W., \& Carton, A. M. (2011). The paradox of stretch goals: organizations in pursuit of the seemingly impossible. Academy of management review , 36, 544-566.

[116]. Smart, D., \& and Conant, J. (1994). Entrepreneurial Orientation, Distinctive Marketing Competencies and Organizational Performance. Journal of Applied Business Research , 10 (3), 28-38. .

[117]. Sonja, M. (2017). The Profitability of Competitive Aggressiveness The Moderating Effect of Industry-Related and. Unpublished Masters thesis Aalto University

[118]. Spender, J. (1996). Making knowledge the basis of a dynamic theory of the firm. Strategic Management Journal, 17(5), 45-62.

[119]. Tachia, C., Sang-Bing, T., Kai, F., Wenzhong, Z., Dongjin, Y., Ren-huai, L., et al. (2016). EO-Performance relationships in Reverse Internationalization by Chinese Global Startup OEMs: Social Networks and Strategic Flexibility. PLoS One. 11(9).

[120]. Teece, D. (2014). A dynamic capabilities-based entrepreneurial theory of the multinational enterprise. Journal of International Business Studies , 45(1), 8-37.

[121]. Teece, D. J., Pisano, G., \&Shuen, A. (1997). Dynamic Capabilities and Strategic Management. Strategic Management Journal , 18, 509-533.

[122]. Tovstiga, G., \&Tulugurova, E. (2009). Intellectual capital practices: a four region comparative study. Journal of Intellectual Capital , 10(1), 70-80. 
[123]. Tukamuhabwa, B., Eyaa, S., \& Derek, F. (2011). Mediating Variables in the Relationship between Market Orientation and Supply Chain Performance: A Theoretical Approach. International Journal of Business and Social Science , 2 (22).

[124]. Udin, R., \& Bose, T. (2014). Entrepreneurial orientation (EO) and performance of business in Khulna City, Bangladesh. Journal of Small Business \&Entrepreneurship , 27(4).

[125]. Venkataraman, S., Sarasvathy, S. D., Dew, N., \& Forster, W. R. ( 2012). Reflections on the 2010 AMR decade award: Whither the promise? Moving forward with entrepreneurship as a science of the artificial. Academy of Management Review, 37(1), 21-33.

[126]. Verona, G. (1999). 'A resource-based-view of product development'. . The Academy of Management Review, 24(1) 132-142. .

[127]. Vishal, K., \&Safal, B. (2015). Entrepreneurial orientation and firm performance in Indian SMEs: Universal and contingency perspectives. Retrieved from http://journals.sagepub.com/doi/abs/10.1177/026624261 5577708 ?journalCode=isbb

[128]. Voss, Z., Voss, G., \& Moorman, C. (2005). An empirical examination of the complex relationships between entrepreneurial orientation and stakeholder support. European Journal of Marketing , 39(9/10),1132-1150.

[129]. W illiams, D. (2009). Determinants of export market destination for outputs from small locally-owned firms. Small Bus. Inst. J. , 4:15-47.

[130]. Waithaka, W. (2016). Relationship between entrepreneurial orientation and performance of small and medium enterprises in the agro based manufacturing sector in Kenya. Unpublished thesis Jomo Kenyatta University of Agriculture and Technology .

[131]. Wales, W., Gupta, V., \& Moussa, F. (2011). Research on EO: Anassesment and suggestions for future research . International Small Business Journal , 31(4),357-383.

[132]. Walter, A., Auer, M., \& Ritter, T. (2006). The impact of network capabilities and entrepreneurial orientation on university spin-off performance", Journal of Business venturing , 21(4),541-567.

[133]. Wambugu, A., Gichira, R., Wanjau, K., \& Mung'atu, J. (2015). The relationship between risk taking and performance of small and medium agro processing enterprises in Kenya. international journal of economics0,commerce and management, III(12).
[134]. Wang, C. L., Senaratne, C., \&Rafiq, M. (2015). Success traps, dynamic capabilities and firm performance. British Journal of Management , 26(1), 26-44.

[135]. Wang, C., \& Ahmed, P. ( 2007). Dynamic capabilities: A review and research agenda. International Journal of Management Reviews , 9(1), 31-51.

[136]. Wang, L. C. (2008). Entrepreneurial orientation, learning orientation, and firm performance.

[137]. Wang, Y., \&Poutziouris, P. (2010). Entrepreneurial risk taking: empirical evidence from UK family firms. Entrepreneurial Behavior \& Research , 16(5), 370- 388

[138]. Weber, J., \& Bolwijn, R. (2014). Investment in Sustainable Development and the role of SMEs UNCTAD World Investment Report . INSME Insights.

[139]. Wiklund, J. (1999). The sustainability of the entrepreneurial orientation -- performance relationship. Entrepreneurship Theory and Practice , 37-48.

[140]. Wiklund, J., \& Shepherd, D. (2011). Where to from Here? EO-as-experimentation, Failure, and Distribution of Outcomes. . Entrepreneurship Theory and Practice, 35(5):925-946.

[141]. Yanlong, Z., \&Xiu'e, Z. (2012). The effect of entrepreneurial orientation on business performance:A role of network capabilities in China. Journal of Chinese Entrepreneurship , 4 (2),132-142,

[142]. Yung-Chul, K. (2013). 'Learning orientation, dynamic capabilities and performance in Korean high-tech ventures'. Advances in Management , 6(4), 54-61.

[143]. Zahra, S. (1991). Predictors and financial outcomes of corporate entrepreneurship: An explorative study. Journal of Business Venturing, , 6(4), 259-285.

[144]. Zahra, S., \& George, G. (2002). Absorptive capacity: A review, reconceptualization and extension. Academy of Management , 27(2), 185-203.

[145]. Zhang, S., van Doorn, J., \& Leeflang, P. (2014). Does the importance of value, brand and relationship equity for customer loyalty differ between Eastern and Western cultures? . International business review , 23 (1), 284-292.

[146]. Zhongfeng, S., En, X., \& Dong, W. (2013). Entrepreneurial Orientation, Managerial Networking, and New Venture Performance in China. Journal of small business management , 53(1)228-248. 